\title{
Water harvesting model for improved rangeland productivity in Butana, Sudan
}

\author{
Elsadig Ahmed Elfaki ${ }^{1}$ Slim Saïdi ${ }^{2 *}$ Ali Mohamed Adeeb ${ }^{3}$ \\ Alexandre Ickowicz ${ }^{2}$
}

\section{Keywords}

Rangeland, biomass, water conservation, rain water management, Spot image, Sudan

Accepted: 21 December 2014; Published: 25 March 2016

\begin{abstract}
Summary
The above-ground biomass and floristic composition of Butana rangelands in Sudan were assessed in 2006 with field surveys covering 25 sites. The remote sensing data derived from Spot image for the same period was integrated to the field surveys to map the spatial distribution of biomass production $\left(\mathrm{kg} \mathrm{ha}^{-1}\right)$ using the perpendicular vegetation index. A rainfall map of the region was established from the meteorological data of the season and the digital elevation model. The rain use efficiency factor, which is the quotient of the annual primary production ( $\mathrm{kg}$ dry matter ha-1) of a season by rainfall $(\mathrm{mm})$ of the same season, was used as a rangeland degradation and desertification indicator in Butana. To test the potential of water harvesting techniques on biomass production, two seasons' experiments were conducted (2006 and 2007). Their results were used to simulate the potential of biomass production with water harvesting application through a general model that linked remote sensing output, field measurement and water harvesting results.
\end{abstract}

- How to cite this article: Elfaki E.A., Saïdi S., Adeeb A.M., Ickowicz A., 2015. Water harvesting model for improved rangeland productivity in Butana, Sudan. Rev. Elev. Med. Vet. Pays Trop., 68 (2-3): 143-147

\section{INTRODUCTION}

Butana spreads across the central clay plains of Sudan. It is located between $14^{\circ} 23^{\prime}$ and $17^{\circ} 34^{\prime} \mathrm{N}$, and $32^{\circ} 32^{\prime}$ and $35^{\circ} 36^{\prime} \mathrm{E}$, and between the Rahad, Blue Nile, Nile and Atbara rivers, covering a surface area of about $120,000 \mathrm{~km}^{2}$ (Figure 1). The area is located in the Sahel zone characterized by climatic and ecological transitions from the savannah in the south to the arid Sahara in the north (Akhtar, 1994), with a tropical arid and semiarid climate and a short summer rainy season (Zaroug, 2000).

\footnotetext{
1. Department of Agricultural Engineering, Faculty of Agricultural Sciences, University of Gezira, Wad Medani, Sudan.

2. CIRAD, UMR SELMET, TAC/112-A, avenue Agropolis, 34398 Montpellier,

France.

3. Water Management and Irrigation Institute, University of Gezira, Wad Medani, Sudan.

* Corresponding author

Email: slim.saidi@libertysurf.fr
}

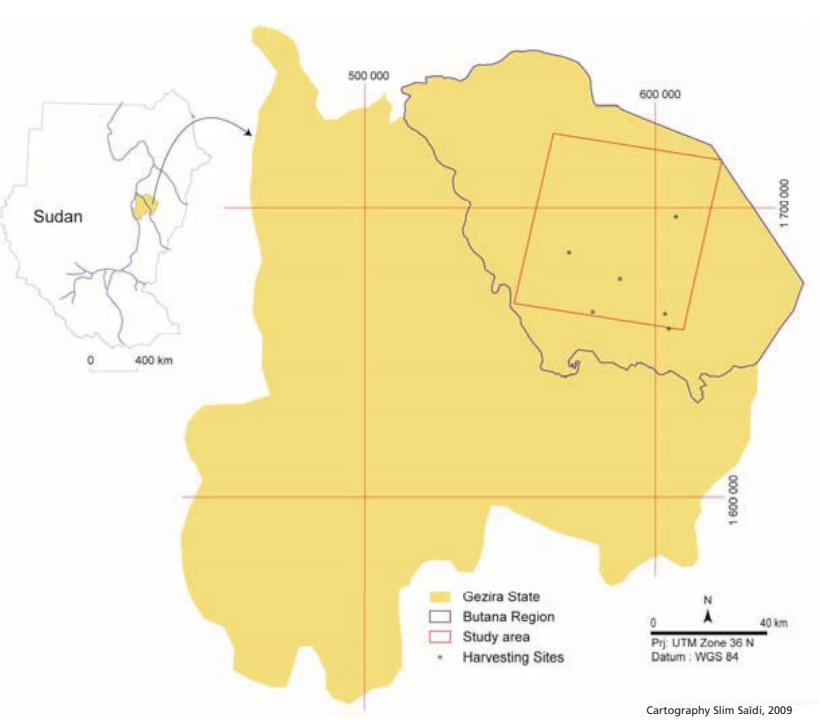

Figure 1: Butana region in Sudan. 
Based on long-term averages, the area is marked by annual precipitation from less than $50 \mathrm{~mm}$ in the North West to $500 \mathrm{~mm}$ in the South East (Olivier, 1965). The extreme spatial and temporal variability of rainfall results from the northward drift of the Intertropical Convergence Zone which leads to an unpredictable rainy season and recurring droughts. The high rainfall variability also triggers a natural shift of vegetation formations over several hundred kilometers (Akhtar, 1994). In addition, Pfloumbaum (1994) reports that this high rainfall variability causes considerable interannual variations in the dry matter production of natural pastures of Sahelian zones.

Generally rainfall is characterized by an uneven distribution (short summer rainy season) and long dry spells that affect crops and range vegetation at critical growth and filling stages, leading to a significant reduction in the total production and productivity of the area experiencing severe degradation.

With declining investments in irrigation in developing countries, alternative methods, such as soil and water conservation, have increased in importance in recent decades (Turral, 1995). Water harvesting is one of them and the technology is based on the collection and concentration of surface runoff for cultivation before it reaches seasonal or perennial streams (Reij et al., 1988). In Sudan, where the major parts are located in arid and semiarid zones, different traditional water harvesting techniques and systems have been used for a long time and are still referred to in the literature by their traditional names, e.g. haffir and teru (Oweis et al., 1999). The objective of this study was to develop a geographic information system (GIS) and remote sensing model to assist in improving the current situation of Butana rangelands, i.e. to increase their productivity and carrying capacity through the application of water harvesting techniques.

\section{MATERIALS AND METHODS}

This study was conducted in Central Butana rangelands whose areas are about $3600 \mathrm{~km}^{2}$ (Figure 1). The current ecological situation of these rangelands was evaluated in 2006 by field surveys covering 25 sites in the region. The above-ground biomass and floristic composition were determined for each site. Remote sensing data derived from Spot image for the same period (Spot View Ortho Basic, date 5/10/2006, columns 7252, rows 6802, projection UTM zone $36 \mathrm{~N}$, datum WGS 84) was integrated to the ground field surveys to create the spatial distribution of biomass production $\left(\mathrm{kg} \mathrm{ha}^{-1}\right)$ by mean of vegetation indices, particularly the perpendicular vegetation index (PVI) (Gintzburger et al., 2005).

A rainfall map of the region was established from the regression correlation between the meteorological data of six stations around the area for the period 1980-2004 and the digital elevation model. The rain use efficiency factor (RUE), which is a quotient of annual primary production $\left[\mathrm{kg}\right.$ dry matter $\left.(\mathrm{DM}) \mathrm{ha}^{-1}\right]$ by rainfall $(\mathrm{mm}$

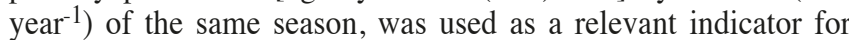
desertification and degradation in the rangelands of arid zones of the world (Gintzburger et al., 2005; Le Houérou, 1984). A review of the RUE methodology applied to arid rangelands is presented by Saïdi and Gintzburger (2013).

The effect of water harvesting techniques on biomass characteristics in Butana region was evaluated with two seasons' experiments (2006 and 2007) on different sites representing two main vegetation and soil units. On each site four rectangular plots of different sizes and parallel to the flow direction were set up (Figure 2). Their surface areas were $60 \times 20 \mathrm{~m}^{2}, 40 \times 20 \mathrm{~m}^{2}, 20 \times 20 \mathrm{~m}^{2}$ and $20 \times 20 \mathrm{~m}^{2}$ (control), respectively. The first three plots were considered as separate catchments and totally enclosed on all sides by earth embankment, whereas the last plot was left open as control. Each of the first three plots was divided into two main units representing the runoff area and the biomass harvesting area. Each plot was also crossed by five separate lines from which the biomass was measured and floristic samples were analyzed.

A general model for water management (Figure 3) was designed using the output results of remote sensing data, the ground surveys and water harvesting experiment findings. The aim was to simulate the potential of biomass production in these rangelands. The model linked the final results of remote sensing and GIS, including a rainfall map, PVI, a biomass map, a rain use efficiency map and a drainage map, to the results of the field measurements of water harvesting and of the surveys.

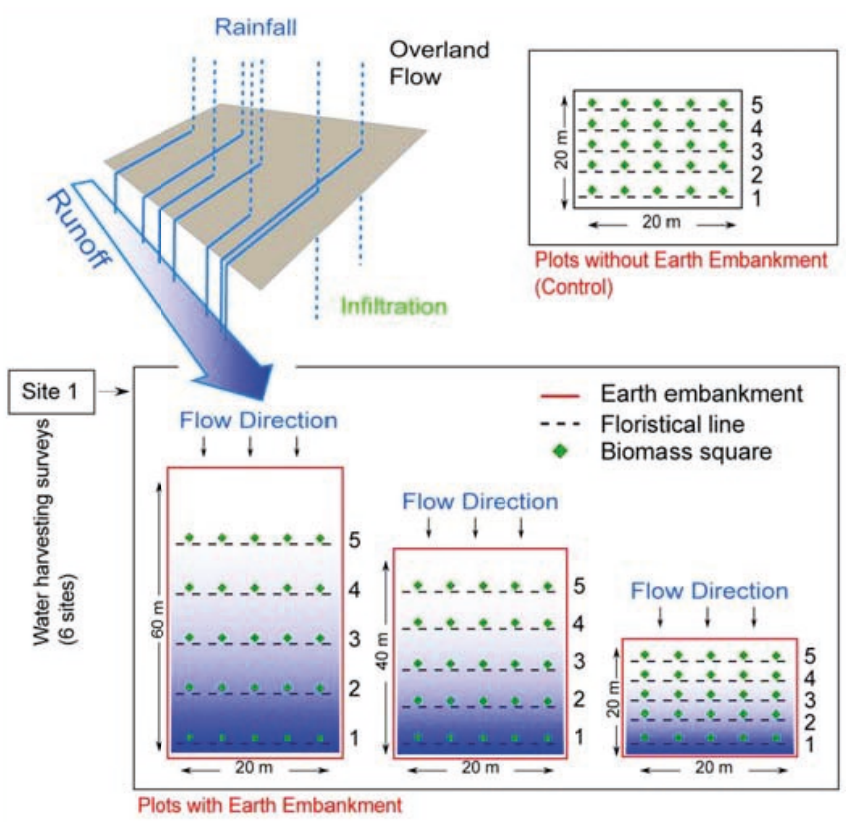

Figure 2: Water-harvesting experiment design (2006-2007).

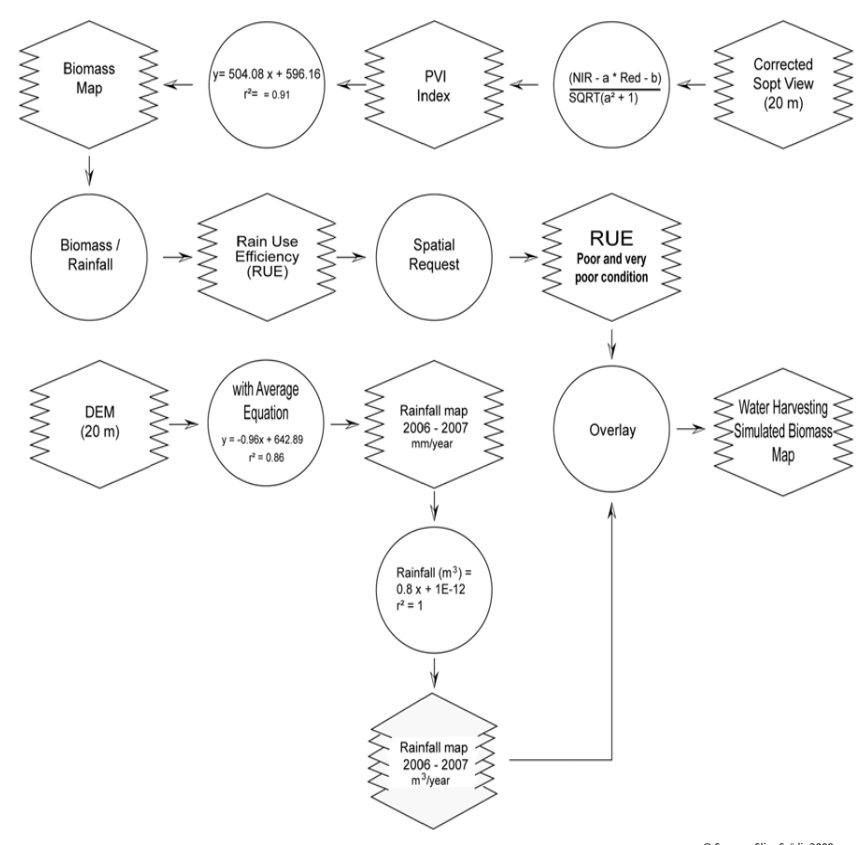

Figure 3: General model of water management used in the central rangelands of Butana, Sudan. 


\section{RESULTS AND DISCUSSION}

The spatial distribution of the RUE factor in Central Butana rangelands (Figure 4) indicated that it was in the range of 0 to $4 \mathrm{~kg} \mathrm{DM}$ $\mathrm{ha}^{-1} \mathrm{~mm}^{-1}$ with an average value of $2.5 \mathrm{~kg} \mathrm{DM} \mathrm{ha} \mathrm{km}^{-1} \mathrm{~mm}^{-1}$ which agreed with Le Houérou and Hoste (1977) who reported a value of $2.7 \mathrm{~kg} \mathrm{DM} \mathrm{ha}^{-1} \mathrm{~mm}^{-1}$ in the Sahel zone. RUE lowest value was found in the Butana high land in the upper rain-water catchment, where water flows fast to depressions and water courses. In areas grown with sorghum, RUE was higher than $4 \mathrm{~kg} \mathrm{DM} \mathrm{ha-1} \mathrm{mm}^{-1}$ as farmers tended to maximize water productivity by water management and water harvesting. Figure 4 shows four RUE classes in Central Butana rangelands. In the almost desertified areas which showed no production, RUE ranged from 0 to less than $1 \mathrm{~kg}$ DM $\mathrm{ha}^{-1} \mathrm{~mm}^{-1}$, in the highly degraded rangelands it ranged from 1 to less than $2 \mathrm{~kg} \mathrm{DM} \mathrm{ha}^{-1} \mathrm{~mm}^{-1}$, in the medium degraded rangelands it ranged from 2 to $3 \mathrm{~kg} \mathrm{DM} \mathrm{ha}{ }^{-1} \mathrm{~mm}^{-1}$, and in the rangelands under good conditions near rain-fed agriculture it ranged from 3 to $4 \mathrm{~kg} \mathrm{DM} \mathrm{ha}{ }^{-1} \mathrm{~mm}^{-1}$.

Results showed that Central Butana rangelands were highly degraded as indicated by the RUE factor map. The situation is the consequence of the high variability of rainfall and the high pressure of animal grazing especially in the rainy season (short summer rainy season). Future development of these rangelands would require the application of many strategies such as soil and water conservation in terms of rain water harvesting to maximize the use of rainfall and hence locally increase rain use efficiency.
Since the main objective of this study was to produce more biomass and maximize water productivity to improve the carrying capacity of Butana rangelands, we found that the production of biomass was a function of the harvested water depending on the size and design of the water harvesting catchment. The biomass produced with water harvesting techniques in the different locations was highly significantly correlated to the harvested water in the two seasons $\left(\mathrm{r}^{2}=0.88\right)$ (Figure 5).

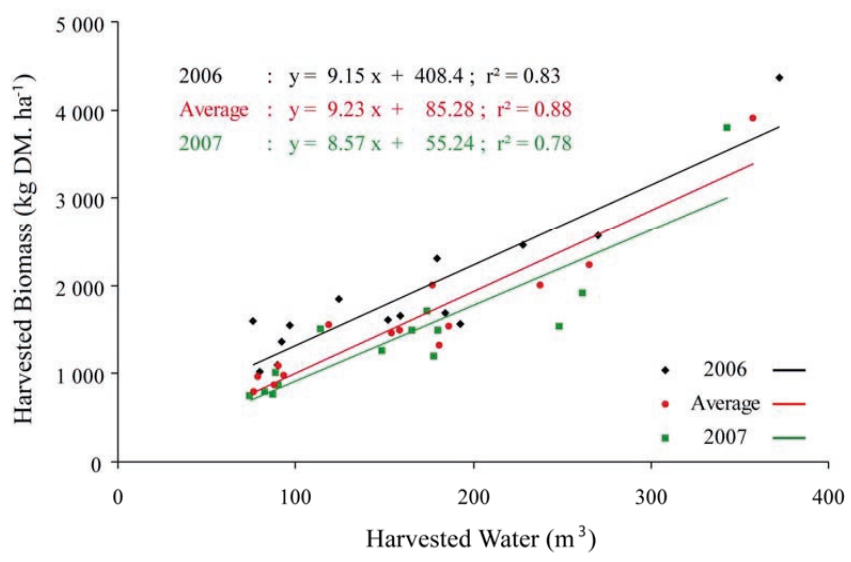

Figure 5: Relationship between harvested biomass and harvested water in the central rangelands of Butana, Sudan.

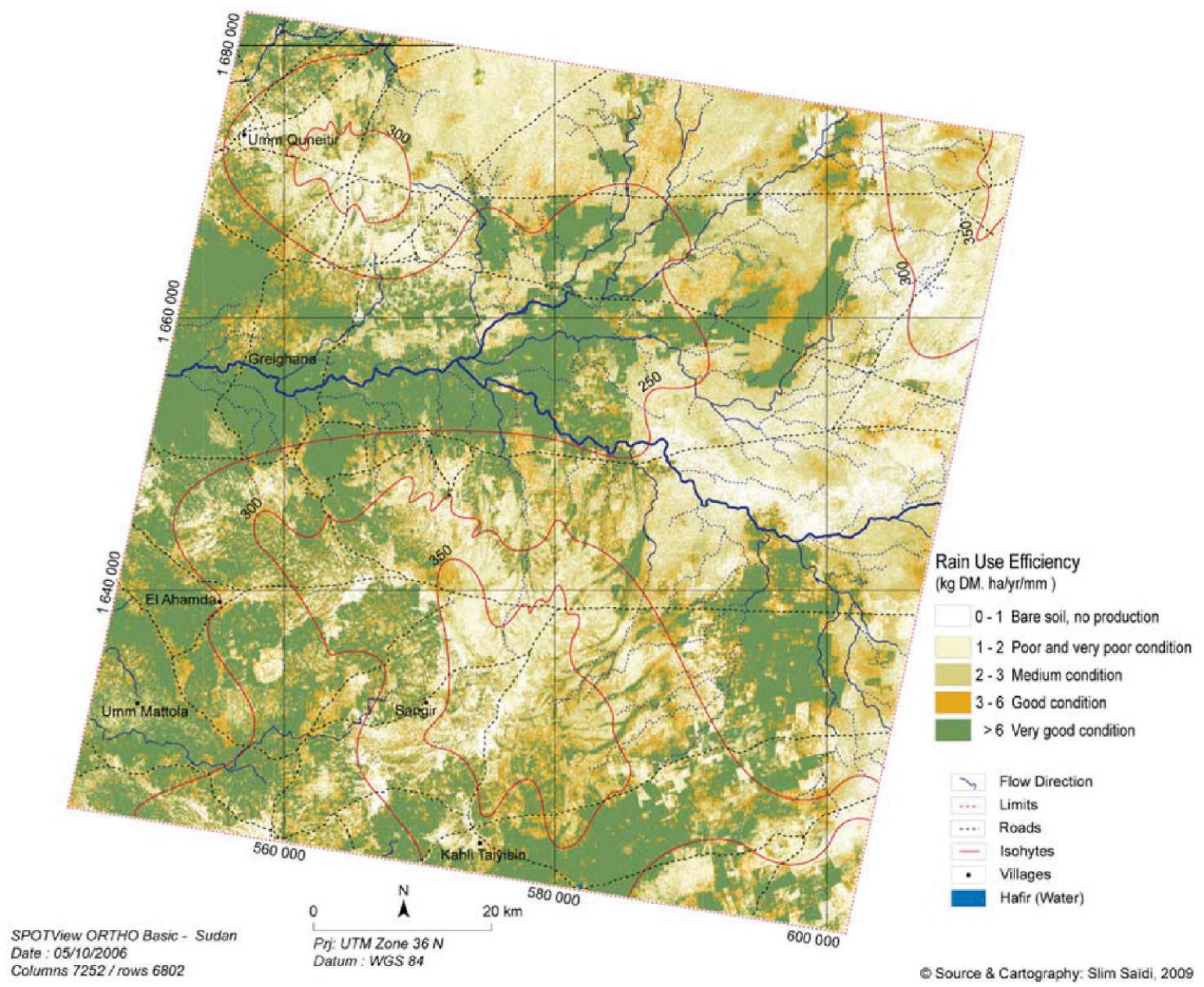

Figure 4: Rain use efficiency map in Central Butana, Sudan. 
The following equation was thus written out:

biomass $\left(\mathrm{kg} \mathrm{ha}^{-1}\right)=9.23$ harvested water $\left(\mathrm{m}^{3}\right)+85.28$

The application of this equation to the general model gives the potential of simulated biomass production $\left(\mathrm{kg} \mathrm{ha}^{-1}\right)$ in relation to the harvested rainfall amount. The suitable areas for water harvesting were identified according to the drainage network derived from DEM.

Figure 6 shows the simulation of biomass that can be produced in Central Butana rangelands when applying water harvesting. The western part of the area (in white) is excluded as it represents rain-fed agriculture. The rest of the area was divided into different homogenous simulated biomass according to the rainfall map and potential runoff. The increase in dry matter production (in green) in the most degraded areas of the rangelands ranged from 350 to $650 \mathrm{~kg} \mathrm{ha}^{-1} \mathrm{yr}^{-1}$ to 2000 to $2200 \mathrm{~kg} \mathrm{ha}^{-1} \mathrm{yr}^{-1}$; the rain use efficiency ratio was thus increased from less than $1 \mathrm{~kg} \mathrm{ha}^{-1} \mathrm{~mm}^{-1}$ to $8 \mathrm{~kg} \mathrm{ha}^{-1} \mathrm{~mm}^{-1}$. In some areas near the drainage network the dry matter production peaked at $2400 \mathrm{~kg} \mathrm{ha}^{-1}$ $\mathrm{yr}^{-1}$. The RUE factor clearly shows that the degraded areas can be regenerated with rainwater harvesting projects which are already in use in Butana. The drainage and potential runoff maps display the potential catchment characteristics to select the suitable areas for water harvesting (shadowy areas along the drainage network) (Figure 6). PVI was used through the model to determine the land use and vegetation pattern in the area impacted by runoff.

\section{CONCLUSION}

As reported by Elfaki (2010), the socioeconomic life of Central Butana is affected by water resources. There is a major interaction between natural resources and the socioeconomic life of Butana's population. Sedentary people's lives are controlled to a large extent by available water resources especially rainfall. Rainfall determines the success or failure of the agricultural season besides its effect on livestock through rangeland vegetation and watering points. Transhumant herders' entire lives are controlled by the pattern and distribution of rainfall, as they determine their decision to come to Butana, their movements, the length of their stay, the family income and the date of reverse migration. Indeed all these factors depend on the availability of water resources in the rangelands. To overcome the problem of rainfall variability, this study presents a decision-support model for water harvesting which can help decision makers and stakeholders determine the suitability of rain water harvesting in any selected part of Central Butana. With the appropriate implementation of runoff techniques in the region as well as the support of the present results, it may significantly improve the livelihoods of Butana people and herders' communities.

\section{Acknowledgments}

We acknowledge G. Gintzburger and late H.N. Le Houérou for their useful discussions and support during the study.

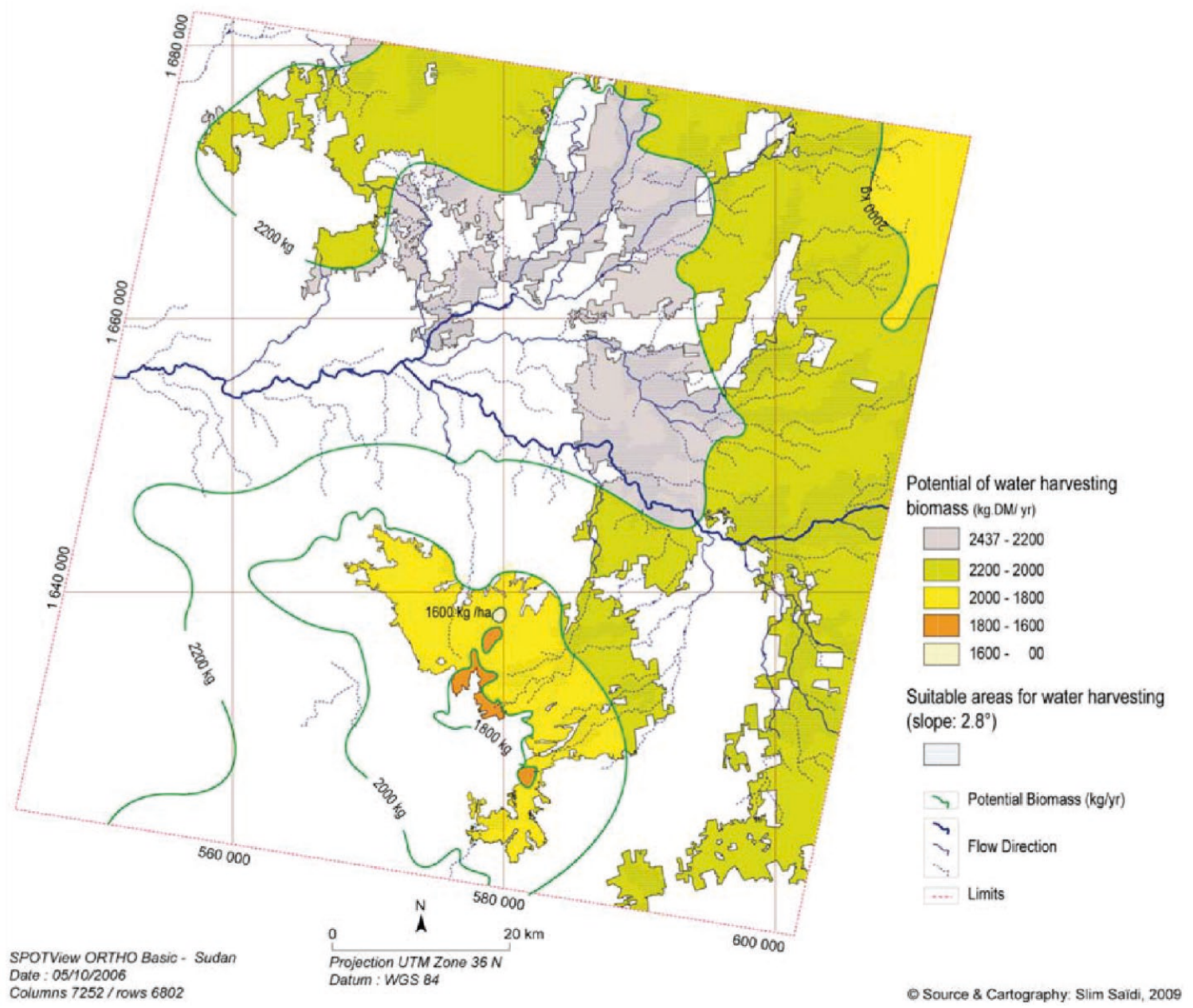

Figure 6: Water-harvesting simulated biomass in Butana, Sudan. 


\section{REFERENCES}

Akhtar M., 1994. Geo-ecosystems and pastoral degradation in the Butana. Anim. Res. Dev., 39: 17-26

Elfaki A.E.A., 2010. Rain water management model for improved rangeland productivity in Central Butana, Sudan. Doct. Thesis, University of Gezira, Sudan, 169 p.

Gintzburger G., Saïdi S., Soti V., 2005. The rangeland of Ravnina Farm in Turkmenistan: Current vegetation condition and utilization. CIRAD, Montpellier, France, 120 p.

Le Houérou H.N., 1984. Rain use efficiency: A unifying concept in aridland ecology. J. Arid Environ., 7: 213-247

Le Houérou H.N., Hoste C.H., 1977. Rangeland production and annual rainfall relations in the Mediterranean Basin and in the African Sahelian and Sudanian zones. J. Range Manage., 30: 181-189

Olivier J., 1965. Evaporation losses and rainfall regime in Central and Northern Sudan. Weather, 20: 58-64
Oweis T., Hachum A., Kijne J., 1999. Water harvesting and supplementary irrigation for improved water use efficiency in dry areas. International Water Management Institute, Colombo, Sri Lanka (Swim Paper 7)

Pfloumbaum H., 1994. Rangeland carrying capacity in the Butana. Anim. Res. Dev., 39: 41-52

Reij C., Mulder P., Begemann L., 1988. Water harvesting for plant production. World Bank, Washington DC, USA (Technical Paper No 91)

Saïdi S., Gintzburger G., 2013. A spatial desertification indicator for Mediterranean arid rangelands: a case study in Algeria. Rangeland J., 35 (1): 47-62

Turral H.,1995. Recent trends in irrigation management. Changing directions for the public sector. ODI, London, UK, 4 p. (Natural Resource Perspectives No 5)

Zaroug M.G., 2000. Country pasture/forage resource profiles - Sudan, grassland and pasture crops, plant production and protection division. www.fao.org/WAICENT/FAOINFO/AGRICULT/AGP/AGPC/doc/ Counprof/SUDAN.htm

\section{Résumé}

Elfaki E.A., Saïdi S., Adeeb A.M., Ickowicz A. Modèle de collecte de l'eau pour améliorer la productivité des parcours dans le Butana au Soudan

La biomasse aérienne et la composition floristique des pâturages du Butana au Soudan ont été évaluées en 2006 à partir d'enquêtes de terrain sur 25 sites. La mise en œuvre de I'indice perpendiculaire de végétation, issu du traitement de l'image Spot, a été couplée aux enquêtes de terrain afin de cartographier la distribution spatiale de la production de biomasse $\left(\mathrm{kg} \mathrm{ha}^{-1}\right)$. La carte des précipitations de la région a été établie à partir des données météorologiques de la saison et du modèle numérique d'élévation. Le coefficient d'efficacité pluviale de la région, qui est le quotient de la production primaire annuelle ( $\mathrm{kg}$ matière sèche $\left.\mathrm{ha}^{-1}\right) \mathrm{d}^{\prime}$ une saison par la quantité de pluie $(\mathrm{mm})$ dans la même saison, a été utilisé comme indicateur de la dégradation et de la désertification des parcours du Butana. Afin de tester l'efficacité des techniques de récupération de l'eau sur la production de biomasse, deux saisons d'expérimentation ont été nécessaires (2006 et 2007). Les résultats obtenus ont permis de simuler le potentiel de production de biomasse à travers un modèle général impliquant conjointement les données télédétectées, les mesures de biomasse des sites de récolte ainsi que la quantité d'eau de surface reçue par chaque site.

Mots-clés : sol de parcours, biomasse, conservation de l'eau, gestion des eaux, eau de pluie, image Spot, Soudan

\section{Resumen}

Elfaki E.A., Saïdi S., Adeeb A.M., Ickowicz A. Modelo de recolección de agua para mejorar la productividad de los pastizales en Butana, Sudán

En 2006, se evaluaron la biomasa superficial y la composición florística de los pastizales en Butana, Sudán, mediante estudios de campo que cubren 25 sitios. Los datos de teledetección procedentes de imagen "Spot" en el mismo período fueron integrados a los estudios de campo, para mapear la distribución espacial de la producción de biomasa (kg ha-1) utilizando el índice de vegetación perpendicular. Se estableció un mapa de precipitaciones de la región a partir de los datos meteorológicos de la estación y el modelo digital de elevación. El factor de eficiencia de uso de la lluvia, que es el cociente entre la producción primaria anual (kg materia seca ha-1) de una temporada de lluvia $(\mathrm{mm})$ de la misma estación, se utilizó como indicador de degradación de los pastizales y desertificación en Butana. Para probar el potencial de las técnicas de recolección de agua sobre la producción de biomasa, se llevaron a cabo experimentos en dos estaciones (2006 y 2007). Sus resultados se utilizaron para simular el potencial de producción de biomasa con la aplicación de la captación de agua, a través de un modelo general que vincula la teledetección de recursos, las mediciones de campo y los resultados de recolección de agua.

Palabras clave: tierra de pastos, biomasa, conservación de agua, ordenación de aguas, agua de Iluvia, imágen Spot, Sudan 
